\title{
Assessing Method to Identifying Water Resilience Against Natural and Climate Change Hazards.
}

\author{
Rofi Amril ${ }^{1}$ and Maryono Maryono ${ }^{2}$ \\ ${ }^{1}$ Master Program of Environmental Science, School of Postgraduate Studies, Diponegoro University, Semarang-Indonesia \\ ${ }^{2}$ Department of urban and Regional Planning, Faculty Engineering, Diponegoro University, Semarang-Indonesia
}

\begin{abstract}
A geographic region may become vulnerable toward water resources in a variety of ways. Common issues arise when man-made infrastructure such as housing, industrial, agriculture and other spatial land use policy implementation exceeds more than desired level. Vulnerability of a region due to water resources could be interpreted as the inability of the region to sustaining economic and social activity associated to socio-economic water availability. This study assess four aspects of water resilience: water quantity, water distribution, water quality, and water requirements. Literature review then followed by interview with academic expert used as method of study. This study found that four aspect of water vulnerability mostly have been applied to asses water resource vulnerability. Each aspect have a specific characteristic and could be define more specific and detail indicator according to the local content.
\end{abstract}

\section{Introduction}

Currently have been more understandable that climate hazard impact influence the balancing of hydrological cycle as shown on the duration of dry and wet season. Water quality and quantity, for example, in Indonesian's river tend to polluted [1]. Moreover, the link between economic development and water resources tend to negative at which cost for water purification becoming bigger day by day [2]. It is a clear sign that water resource vulnerability clearly arise. Assessing the water contribution for development and the vice versa the impact of development toward increasing water have been conducted, however the increasing of water vulnerability should be evaluate since the issues will influence more significant the relationship. Moreover increasing the living standard also influence to the water competition among users.

The demand for water already exceeds the available supply in many regions and river basins, especially in parts of Asia, North Africa and the Middle East, and subSaharan Africa - where the majority of poor people live and where the population is growing most rapidly. Global fresh water withdrawals have been growing at a rate of about $1 \%$ annually since the $1980 \mathrm{~s}$, almost entirely in developing countries. Global water demand will be increase for $20-130 \%$ for post 1990, and it is significant change compare to the increasing of water global demand pre 1990 [3]. The rapid increasing of water cause by dominant sector such as industrial and domestic use, energy production, and agriculture [3,4].

Over the past several decades, food production as a result of the green revolution has improved dramatically, concerning to access to drinking water that increase for 2.4 billion people, while access to sanitation facilities improved for 600 million since 1980 [4]. Moreover, concerning to the data trend, a systemic water crisis due unsustainable management of water resources, a poor social, environmental, economic policies is then clearly understandable. Therefore at the same time, there is a need to increase water supplies and services to fulfill population growth, in an environmentally sound manner. It is also clearly note that the traditional problems concerning the provision of water supply and sanitation services in urban and rural areas will require more specific efforts to solve, since more than a billion people do not have access to potable water supply and 3 billion do not have adequate sanitation [4]. If there is no policy transformation, the rapid population growth, food security and growing energy and electricity, domestic supply, and industrial development will face a huge problem concerning to the water availability. Moreover the climate hazard will impact seriously to the water resilience.

Concerning to the availability and vulnerability of water, this study will assess the possibility method to identifying water resilience.

\section{Literature review: water resilience}

Many study concerning to water resilience have been conducted worldwide. One of the principle water resilience is associated to the Institutional and ecological engineering, for example, concerning to parameter of policy of land use, spatial waters management [5]. Water resilience also have a correlation with the adaptive

\footnotetext{
Corresponding author: maryono@pwk.undip.ac.id
} 
government especially for the ability of government to design law enforcement to cover the spatial planning issues [6]. Water resilience could be defined associated with the influence to the food production [7], and sustainable cities and regional economic development $[8,9]$. Other importance issue of water resilience is the water supply associated with the water demand especially in drought season [10]. The characteristic of the water resilience in dry season usually suffer in rural and mountain area. However, in specific condition also suffer in coastal zone.

This study assess four basic aspects of water resilience: water quantity, temporal distribution, water quality, and water requirements. Water quantity associated to the availability to support development both in local or regional region is decrease in recent decade $[3,4]$. Therefore the development agenda such as SGs 2030 need specific and applicable indicator for water issues. In the context of water distribution water issues also need specific spatial management to solve the un-balance situation $[3,8]$. It is known that the Water quality is the most importance parameter in water services [11]. Increasing the quality of life and degree of economic development recently affect to the requirement of water, in vice versa climate hazard arise from the un proper rapid development.

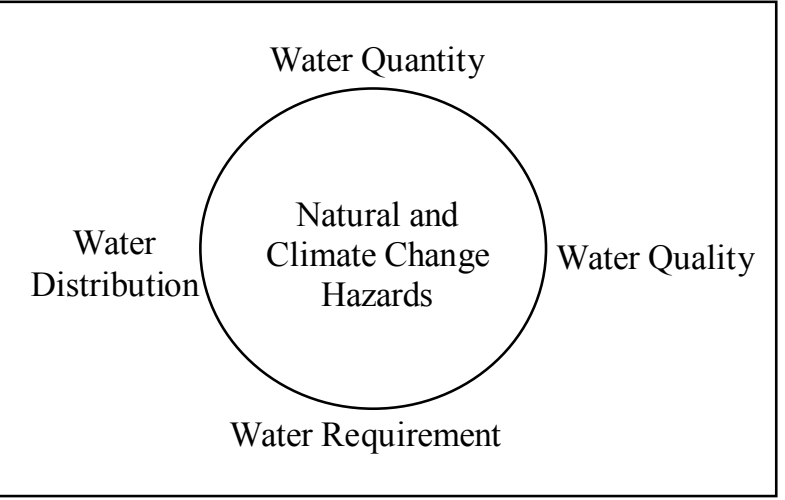

Fig. 1. Parameter and aspect of water resilience against natural and climate change hazards.

\section{Methodology}

\subsection{Study area and issues}

As shown in figure 2, Agam Regency is selected as study area. The Agam Regency is part of West Sumatra Province. The west Sumatra, including Agam Regency is one of the vulnerable region in Indonesia. It was attacked huge earthquake in 2009. The victim such as 1,117 people death, 1214 people hard injure, 1168 medium injure. 135.448 housing was hard damage, 65.380 housing was medium damage, and 78.604 housing was low damage [14]. While in 2010 Tsunami disaster attacked Mentawai Island near to the study area also with huge victim, damage and losses[15].

In 2010 the number of population are 455.484 and the growth rate of population is $0.93 \%$, The population is distributed within 16 district, 82 Nagari and 467 Jorong [13]. Since this regency in one of the vulnerable region due to the earthquake, tsunami and climate hazard, the study of water resilience is very importance to fostering the community resilience.

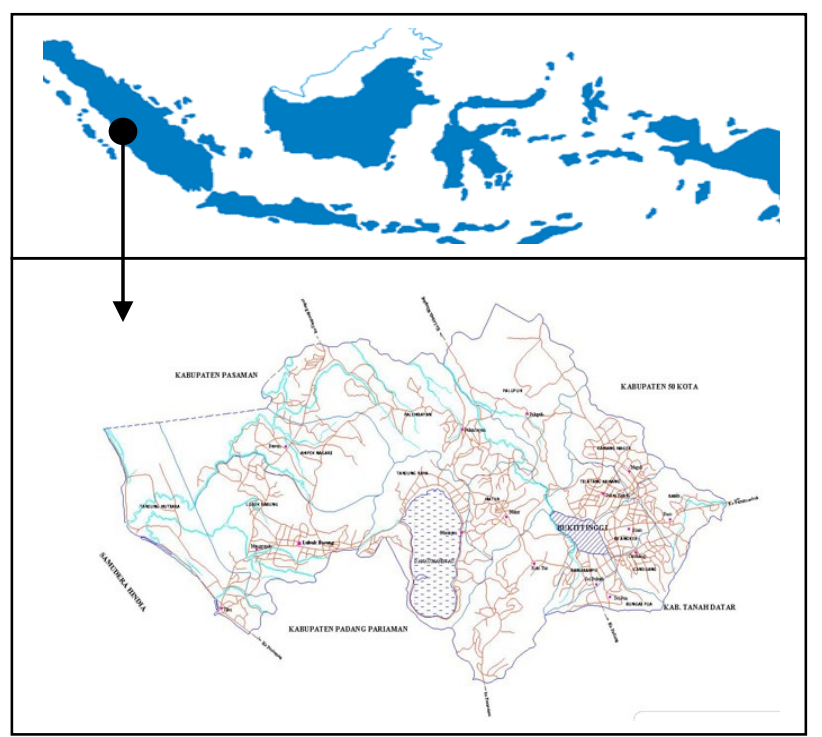

Fig. 2. Location and Map of Agam Regency [13]

\subsection{Scope, data collection and analysis}

This study assessed four aspect of water resilience; water requirement, water quality, water quantity and water distribution. Assessing of water requirement and water distribution by using quantitative model while water quantity and water quality by using qualitative descriptive refers to the formal regulation. Data concerning to the water resilience will be collected from the secondary data. Quantitative model of water resilience describe as follow.

\subsubsection{Water requirement}

Water requirement assessed by using the formula and model of the water requirement as follow :

$$
W t=\left(P o(1+r)^{n}\right) * 60 \frac{L}{\text { capita }}
$$

Where

$$
\begin{array}{ll}
\mathrm{W}_{\mathrm{t}} & \text { : water requirement for year } \mathrm{t} \\
\mathrm{P}_{\mathrm{o}} & \text { : Population in base year assessment } \\
\mathrm{r} & \text { : rate of population growth } \\
\mathrm{n} & \text { : the different of year (year prediction and } \\
& \text { base assessment) } \\
\mathrm{L} & \text { : unit of water in Liter }\left(0.001 \mathrm{~m}^{3}\right) \\
\text { Capita } & \text { : unit of people. }
\end{array}
$$

\subsection{2 water distribution}

Water distribution resilience assessed by using the model of total water requirement divided by total requirement in each district. Water distribution calculated by model as follow 


$$
W i=\left(\left(P o(1+r)^{n}\right) * 60 \frac{L}{\text { capita }}\right) / W T
$$

Where
$\mathrm{w}_{\mathrm{i}} \quad$ : Water distribution for region i for year $\mathrm{t}$
$\mathrm{P}_{\mathrm{o}} \quad$ : Population in base year assessment
$\mathrm{r} \quad$ : rate of population growth
$\mathrm{n} \quad$ : the different of year (year prediction and
base assessment)
L : : unit of water in Liter $\left(0.001 \mathrm{~m}^{3}\right)$
Capita : unit of people.
WT : Total Water requirement for year $t$ for

\section{Result and discussion}

One of the aspect of the water resilience is concerning to the requirement. As shown in table 1, water requirement in Agam for year 2040 totally 33.077 $\mathrm{m}^{3}$. The number is calculated by using the assumption that the population growth is $0,93 \%$ and it is fix for 30 years of calculation. In the district level, the highest of requirement is Lubuk Basung regency with estimated $5.402 \mathrm{~m}^{3}$. While the lowest is Malalak regency estimated $737 \mathrm{~m}^{3}$. When the government supply the number of the water requirement the ideal resilience of water will be achieved. Moreover, the degree of resilience is depending of the level of water services.

Table 1. Water Requirement in Agam Regency for year 2040

\begin{tabular}{|l|c|c|c|}
\hline $\begin{array}{l}\text { District in } \\
\text { Agam Regency }\end{array}$ & $\begin{array}{c}\text { Year } \\
\mathbf{2 0 1 0}\end{array}$ & $\begin{array}{c}\text { Year } \\
\mathbf{2 0 4 0}\end{array}$ & $\begin{array}{c}\text { Water } \\
\text { Requirement 2040 } \\
(\mathbf{m 3 )}\end{array}$ \\
\hline $\begin{array}{l}\text { Tanjung } \\
\text { Mutiara }\end{array}$ & 28.311 & 37.373 & 2.242 \\
\hline Lubuk Basung & 68.198 & 90.028 & 5.402 \\
\hline Ampek Nagari & 22.570 & 29.795 & 1.788 \\
\hline Tanjung Raya & 33.307 & 43.969 & 2.638 \\
\hline Matur & 16.944 & 22.368 & 1.342 \\
\hline IV Koto & 23.036 & 30.410 & 1.825 \\
\hline Malalak & 9.299 & 12.276 & 737 \\
\hline Banuhampu & 36.059 & 47.602 & 2.856 \\
\hline Sungai Pua & 23.042 & 30.418 & 1.825 \\
\hline Ampek Angkek & 43.347 & 57.223 & 3.433 \\
\hline Canduang & 21.886 & 28.892 & 1.734 \\
\hline Baso & 33.016 & 43.585 & 2.615 \\
\hline $\begin{array}{l}\text { Tilatang } \\
\text { Kamang }\end{array}$ & 34.027 & 44.919 & 2.695 \\
\hline Kamang Magek & 19.972 & 26.365 & 1.582 \\
\hline Palembayan & 29.426 & 38.845 & 2.331 \\
\hline Palupuh & 13.044 & 17.219 & 1.033 \\
\hline $\begin{array}{l}\text { Rotal of Agam } \\
\text { Regency }\end{array}$ & 455.484 & 601.286 & 36.077 \\
\hline
\end{tabular}

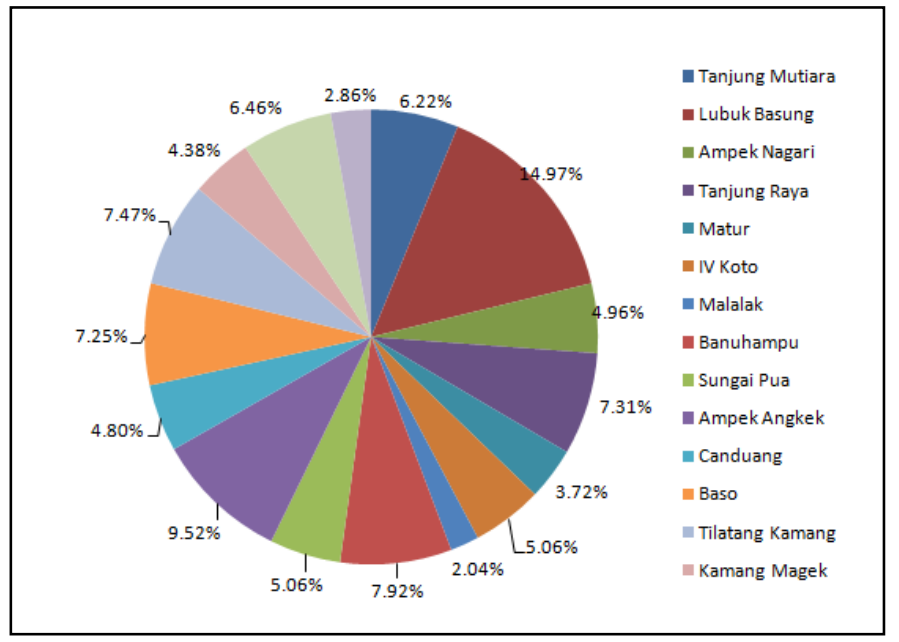

Fig. 2. Water Distribution at Agam Regency for year 2040 base on district level.

The distribution of water requirement in Agam for year 2040 depicted in figure 2. According the calculation the highest propeortion of distribution is lubuk basung district with estimated $14,97 \%$ while the lowest proportion is malalak district with estimated 2,04\% comparing to the total of water requirement in Agam. The calculation of the distribution is conducted by using the formula of total requirement in district divided by the total number of regency. The assumption of this proportion is that the number of population growth is fix for $0.93 \%$ per year for 30 years and the number of percapita of water requirement also fix $60 \mathrm{l} /$ capita.

Water quality for year 2040 in Agam regency may be change depending on the policy and law performance. Control of water quality need stakeholder effort and detail understanding of whole resilience aspect. WHO have been issued guidelines for water drinking quality [16]. Moreover stakeholder intention to prepare and mitigate the water pollution is very needed. Moreover to prepare and fostering resilience in water and sanitation there were some factors that may be considered [17].

Water quantity is different with water requirement. The water quantity content terminology of logistic. It is concerning to the number of water that storage in region in the condition and high level of readiness. The quantity of water could be defined as the capability of government to provide water not only the current situation, but also for future years. Water quantity means conducting sustainable water provision [17]. The parameter of assessment also associated with the number of water for all purpose not only for domestic sector.

\section{Conclusion}

- This study assessed four method to assess and identify water resilience namely water quantity, water distribution, water quality, and water requirements.

- Method to identifying waster requirement resilience could be developed by using simple mathematic model until complex model. This 
study proposes the model by combining population growth and standard of daily water need percapita.

- The assessment of water distribution could be asses by development mathematical model such as base on district level. This study propose model according to the requirement of water in district level.

- This study proposed that method to identifying the water resilience concerning to the water quality and quantity is by assessing the stakeholder intention. Since this aspect in associated to the understanding and behaviour.

\section{Acknowledgment}

This research is funded by the Directorate of Research and Community Services, Ministry of Research, Technology and Higher Education for year 2017 with contract number 344-42/UN7.5.1/PP/2017

\section{References}

1. M.A. Shannon, P.W. Bohn, M. Elimelech, J.G. Georgiadis, B.J. Marinas, A.M., Mayes, Nature, Vol 452, pp. 301-310, (2008).

2. B.P. Resosudarmo, Int.J. Environ and Sus Dev, Vol 2, no.1.pp. 62-77. (2003).

3. U.A. Amarasinghe, V smakhtin, Global Water Demand Projections: Past, Present and Future Global water demand projections: past, present and future. (IWMI Research Report 156). doi: 10.5337/2014.212, (2014)

4. J. Alcamo, P Doll, . Hendrichs, F. Kaspar, B. Lehner, T. Rosch, S. Siebert, Hydrological Sci. J. vol 48.no3. pp. 339-348, (2003)
5. M Falkenmark, J Rockström, J. Water Resour. Plann. Manage. 136(6): 606-610. (2010)

6. M. H. Clarvis, A. Alan, D.M. Hannah, Envi Science \& Pol, 43, pp 98-110 (2014)

7. J Rockström, M Falkenmark, L Karlberg, H.Hoff, S. Rost, D. Gerten, Water Resources, 45 (2009)

8. S Barthel, C Isendahl - Ecological Economics, 86.pp. 224-234 (2013)

9. A Rose, S.Y Liao - J. Reg Sci, 45.1. pp. 75-112. (2005)

10. J Rockström, Physics and Chemistry of the Earth, 28. 20 pp. 869-877 (2003)

11. A. Milman, A short, Glob Envi Change,18, pp. 758767 (2008)

12. J.Rockström, M. Falkenmark, C. Folke, M. Lannerstad, J. Barron, E. Enfors, L. Gordon, J. Heinke, H. Hoff, C. Pahl-Wost, Water resilience for human prosperity. Cambridge University Press, (2014).

13. The government of Agam Regency, Peta Kabupaten Agam, 2017, available on http://www.agamkab.go.id/?agam=profil\&se=peta, access January, 2017

14. The BNPB, Bappenas, Provincial and District/City Governments of West Sumatra and Jambi and international partners Damage, Loss and Preliminary Needs Assessment, Joint report (2009)

15. A. V. Newman, G. Hayes, Y. Wei, \& J. Convers, Geophysical Research Letters, 38.5. (2011)

16. WHO, Guidelines for drinking-water quality, 2004

17. Maryono, H. Nakayama, T. Shimaoka, Memoir of faculty Engineering, Kyushu Univeristy, Vol.74 no 3, pp.79-98

18. P. Chaves, T Kojiri, Y Yamashiki, Hydrological Processes, 17(14), 2769-2793.

(2003) 